Jacek Szymala

Uniwersytet Wrocławski

ORCID 0000-0002-8714-7114

Andrei Rogatchevski

UiT The Arctic University of Norway

ORCID 0000-0003-3326-8719

\title{
Filmowe portrety Stanisława Siedleckiego (1912-2002) na tle Svalbardu. Fragmenty wizualnej historii nauki
}

\section{Stanisław Siedlecki's (| 9 | 2-2002) Film Portraits against the Backdrop of Svalbard. Vignettes from the Visual History of Science}

The article offers a new perspective on Stanisław Siedlecki's biography through visual history, with a particular emphasis on film history. The connections between Siedlecki's life and the cinema can be grouped in three sections: 1. films starring Siedlecki, 2. films by Siedlecki and 3. films about Siedlecki. The film Do Ziemi Torella (To Torell Land) represents the pre-war period; the post-war period is marked by Siedlecki's collaboration with Jarosław Brzozowcki on the making of Skroplone Powietrze (Liquefied Air) and Wieliczka - both from 1946. In the International Geophysical Year 1957/1958, Siedlecki led the Polish polar expedition, during which the visual material was created. He appeared in all three 'roles' (as a co-writer, protagonist, and consultant) in Jarosław Brzozowski's film W Zatoce Białych Niedźwiedzi (In the Polar Bear Bay). He consulted polar films until the early 1990s. There are also two film biographies (portraits) of Siedlecki by Wanda Rollna and Iwona Bartólewska. The analysis of this material has also shed new light on the visual narration of the Polish polar expeditions in the $20^{\text {th }}$ century.

Keywords: Stanisław Siedlecki, Svalbard, Polish film, northern

Słowa kluczowe: Stanisław Siedlecki, Svalbard, film polski, northern

Oglądając płaskorzeźby przedstawiające historię Ramy na ścianach świątyni Sziwy, pisze prof. M[ichał] Siedlecki [ojciec Stanisława Siedleckiego] tak; „Mnie jako przyrodnika zajmuje nie tylko treść obrazów i ich wartość artystyczna, lecz także zwracały mą uwagę postacie zwierząt i roślin"1. 
Sylwetka i dorobek naukowy Stanisława Siedleckiego (1912-2002) są dobrze znane badaczom, przede wszystkim zajmującym się naukami o Ziemi, w tym szczególnie geologom². Dekadę po jego śmierci opublikowano dwa opracowania autorstwa Piotra Köhlera poświęcone osobie Siedleckiego jako „polarnika, taternika i geologa” oraz jego spuściźnie. Postać ta znana jest dobrze naukowcom zajmującym się badaniami Arktyki, jak również historią tych badań, w tym narracjami polarnymi ${ }^{4}$.

W niniejszym opracowaniu proponujemy przyjrzenie się fragmentom życiorysu Siedleckiego przez pryzmat historii wizualnej, szczególnie filmowej. Wychodzimy z założeń o interdyscyplinarności subdyscypliny, jaką jest historia wizualna, oraz z tezy o pokrewieństwie humanistyki z przyrodoznawstwem, której wyraz stanowi przywołane powyżej motto ${ }^{5}$. Spróbujemy uporządkować i omówić związki Siedleckiego z historią filmu, w tym z tradycjami filmowania Svalbardu, zwłaszcza przez polskich filmowców (od lat trzydziestych do dziewięćdziesiątych XX w.). Można na wstępie zaproponować kilka punktów styczności biografii Siedleckiego z historią kina:

1. Siedlecki jako „aktor” w roli samego siebie - członek ekspedycji na Spitsbergen (Svalbard) w filmie Do Ziemi Torella (1934);

2. Siedlecki jako filmowiec - scenarzysta filmów Wieliczka oraz Skroplone powietrze (oba z 1946 r.); także jako autor filmów zrealizowanych na Svalbardzie na amatorskiej taśmie $8 \mathrm{~mm}$;

3. Siedlecki jako inicjator i organizator ekspedycji na Spitsbergen podczas Międzynarodowego Roku Polarnego 1957/1958 (nie tylko jako sfilmowany kierownik wyprawy, lecz także w szerszym ujęciu - jego rola w powstaniu filmów Włodzimierza Puchalskiego i Jarosława Brzozowskiego);

4. Siedlecki jako konsultant filmów o tematyce polarnej (od lat sześćdziesiątych do dziewięćdziesiątych XX w.).

W uproszczeniu związki biografii Siedleckiego z filmem dają się zebrać w trzech konstelacjach: Siedlecki w filmach; filmy Siedleckiego; filmy o Siedleckim. Jako materiał źródłowy posłużą nam głównie same filmy (wypowiedzi Siedleckiego, jak i innych osób na

2 Siedlecki rozpoczął prace geologiczne po wojnie. Początkowo zajmował się kartowaniem geologicznym; pracował w terenie Górnośląskiego Zagłębia Węglowego (region śląsko-krakowski). W 1953 r. zainicjował i zredagował cztery pierwsze tomy serii wydawniczej Materiały do geologii obszaru śląsko-krakowskiego. Jako ekspert w dziedzinie geologii współpracował z Przedsiębiorstwem Poszukiwań Naftowych (1958-1963). Od wiosny 1956 r. pracował w Zakładzie Geologii Polskiej Akademii Nauk, a po organizacji wypraw na Svalbard przeniósł się do Norwegii (w latach 1964-1966 pracował w Norweskim Instytucie Polarnym w Oslo, w 19661978 w Norweskim Instytucie Geologicznym w Trondheim). Por. przyp. 1 i 3.

3 P. Köhler, Stanisław Siedlecki (1912-2002) - polarnik, taternik, geolog. Stulecie urodzin, [w:] „Kwartalnik Historii Nauki i Techniki" t. 58, 2013, nr 3, s. 61-80; idem, Spuścizna Stanisława Siedleckiego (1912-2002) w zbiorach Zakładu Badań i Dokumentacji Polarnej im. Prof. Zdzisława Czeppego Instytutu Botaniki Uniwersytetu Jagiellońskiego, „Krakowski Rocznik Archiwalny” t. 18, 2012, s. 157-176.

4 Zob. Pamiątkowa księga przyjaźni. Stanisław Siedlecki, red. R.W. Schramm, Poznań 1992 (tom jubileuszowy); po śmierci Siedleckiego, który „odszedł od nas na wieczne zimowanie 7 marca 2002 roku w wieku 90 lat”, teksty wspomnieniowe opublikowano w „Biuletynie Polarnym”. Cyt. Z. Manecki, Od redakcji, „Biuletyn Polarny” 2002, nr 11, s. 5.

5 Por. R. Dyboski, M. Siedlecki, Przyrodnik a humanista. Dialog, [w:] „Przegląd Współczesny” t. 60, 1937, s. $100-107$. Dialog ten miał miejsce sześćdziesiąt lat przed publikacją książki Edwarda O. Wilsona Konsiliencja. Jedność wiedzy (1998; przekład polski 2002), która m.in. opowiada się za jednością nauk humanistycznych i przyrodniczych. 
jego temat, zarejestrowane przez filmowców), w miarę możliwości skorzystamy także z wszelkich opublikowanych wzmianek prasowych, w których można zauważyć związki Siedleckiego z filmem, w tym wzmianki i komentarze jego samego. Można w ramach wstępu stwierdzić, że w biografii Siedleckiego niczym w soczewce wyraźnie rysuje się powojenna polska historia (polskich) wypraw polarnych. Uczony miał wpływ na filmowe świadectwa tych wypraw niezależnie od roli, jaką pełnił na planie filmowym.

\section{Okres przedwojenny}

Od początku historii polskich wypraw polarnych (czyli od lat trzydziestych XX w.) porównywano klimat Svalbardu z Tatrami, wskazując na swojski charakter tego miejsca. W filmie dokumentalnym z 1988 r. Siedlecki wspominał, że gdy miał piętnaście lat (tzn. w drugiej połowie lat dwudziestych), zaczęła się jego pasja do gór. Udając się w ramach Międzynarodowego Roku Polarnego 1932/1933 na Wyspę Niedźwiedzią miał już bogate doświadczenia wysokogórskie i alpinistyczne. W zbiorach Zakładu Badań i Dokumentacji Polarnej im. Prof. Z. Czeppego Instytutu Botaniki UJ zachował się dwutomowy album Siedleckiego dokumentujący pobyt na Wyspie Niedźwiedziej, zawierający po 38 kart z fotografiami z wyprawy ${ }^{6}$. Zarówno w tych materiałach, jak też w późniejszych fotografiach z wyprawy na Spitsbergen w 1934 r. oraz w filmie Do Ziemi Torella7, góry Svalbardu stanowią istotny motyw wizualny. Warto podkreślić, że autorem niektórych fotografii był sam Siedlecki.

Z kolei jako „aktor" występujący w roli samego siebie w filmie Do Ziemi Torella, jako najmłodszy uczestnik wyprawy, miał - jak się zdaje - nie tylko największe doświadczenie jako polarnik (został nawet scharakteryzowany jako „doświadczony polarnik”) oraz alpinista, lecz widać także, że był oswojony z kamerą - ujęcia z Siedleckim w największej mierze przypominają profesjonalne aktorstwo, w odróżnieniu od innych członków wyprawy, a zwłaszcza zmieszanego wyraźnie Antoniego B. Dobrowolskiego, sfilmowanego jako wykładowca w prologu filmu.

Pewnym symbolicznym momentem, punktem styczności historii filmu (zwłaszcza jeśli mówimy o filmowych „northernach”, szczególnie ze Svalbardem) z biografią Siedleckiego jest jego uczestnictwo w premierowym pokazie Do Ziemi Torella w Oslo 16 września 1936 r. Uczestnicy pokazu mogli obejrzeć jeszcze świeżą audiowizualną relację (reportaż) z niedawnej polskiej wyprawy, a jednego z członków-aktorów zarówno na ekranie, jak i na żywo. Można sobie wyobrazić takie zachowania widowni, jak naprzemienne spojrzenia lepiej zorientowanych (lub uważnych) to na ekran, to na Siedleckiego. Być może nawet „aktor" po seansie ukłonił się, symbolicznie dziękując za przybycie (zwłaszcza jeśli

6 Por. A. Lubowicka, Jak dołączyć do grona „państw kulturalnych”. Historia wizualna pierwszej polskiej ekspedycji arktycznej w dwudziestoleciu międzywojennym, [w:] Okno na przeszłość. Szkice z historii wizualnej, t. 2, red. D. Skotarczak, J. Szymala, Kraków 2020, s. 35-70.

7 Szerzej na ten temat zob. J. Szymala, A. Rogatchevski, Svalbard w filmach polskich z lat 30. XX w., „Kwartalnik Filmowy" 2020, nr 112, s. 161-180.

8 Na temat gatunku filmowego „northernu” zob. szerzej: S. MacKenzie, A. Westerståhl, The Polarities and Hybridities of Arctic Cinemas, [w:] The Oxford Handbook of Canadian Cinema, red. J. Marchessault, W. Straw, New York 2019, s. 1-2. 
przyjmiemy, że był obecny w sali kinowej jako jedyny uczestnik sfilmowanej przez Witolda Biernawskiego ekspedycji) ${ }^{9}$.

W czasopiśmie „Norsk Tidend” z 18 września 1936 r. znajduje się tekst zatytułowany Polakkar krossar Svalbard på langs, czyli Polacy przemierzają wzdłuż Svalbard, opatrzony dwoma podtytułami: $850 \mathrm{~km}$ med slede og ski (850 km na sankach i nartach) i Dr Siedlecki fortel um polsk ishavsliv (Dr Siedlecki opowiada nam o polskim życiu w Arktyce). Artykuł sygnowany akronimem „V." opowiada o pokazie Do Ziemi Torella w kinie Victoria w Oslo 16 września 1936 r., podczas którego był obecny Siedlecki. Jako że niedawno wrócił z innej ekspedycji na Svalbard, na saniach i nartach wzdłuż Vest-Svalbardlandet z Sørkapplandet do Verlegenpynten (wraz ze Stefanem Bernadzikiewiczem i Konstantym Narkiewiczem-Jodko ${ }^{10}{ }^{0}$, dziennikarz skorzystał ze sposobności zapytania go o podróż i wcześniejsze wizyty Siedleckiego na archipelagu. Siedlecki wystąpił w roli tłumacza wyprawy z 1936 r. ${ }^{11}$ Mówił zabawną mieszanką literackiego języka norweskiego z dialektem nordlandzkim, z akcentem gdzieś pomiędzy:

- To była piękna wyprawa (mówi Siedlecki). Odpowiednio ekscytująca i odpowiednio męcząca. Tym razem nie dokonaliśmy wielu obserwacji naukowych. Chcieliśmy tylko osiągnąć jakiś niezły wynik sportowy (uśmiecha się skromnie). Oczywiście przywieźliśmy trochę materiału, z którym będziemy pracować, kiedy wrócimy do Warszawy. Statek Lyngen z Tromsø wylądował w Hornsundzie. I tutaj na początku prawie się nie udało. Byliśmy zmęczeni morską podróżą i chcieliśmy natychmiast włączyć czajnik. Potem odkryliśmy, że kupiec z Tromsø dał nam spirytus metylowy zamiast benzyny do naszej kuchenki. Utknęliśmy [wobec perspektywy, jaką była] miesięczna wędrówka do najbliższej stacji benzynowej. Na szczęście o milę na południe od Hornsundu zobaczyliśmy łódź rybacką. Poszliśmy jej szukać i zaczęliśmy krzyczeć. W tym momencie wypływał z fiordu na pełnej parze. Ludzie na pokładzie dali nam benzynę - i nawet nie wspominali o zapłacie. Traperzy są zawsze bardzo uprzejmi (mówi poważnie). Poza tym wycieczka nie była szczególnie rewelacyjna. Mieliśmy burzę śnieżną i musieliśmy przemierzać lodowce i pęknięcia lodowe. Ale nie ma się czym chwalić Norwegom (dodaje). Z drugiej strony, ta podróż była właściwie zapowiedzią dużej wyprawy, którą planujemy na następny rok. Zdobyliśmy przydatne umiejętności w zakresie sprzętu i jedzenia.

- Jak podobała Ci się rok wcześniejsza wyprawa na Wyspę Niedźwiedzią [w 19321933].

- Byłem tak zajęty badaniami meteorologicznymi i geologicznymi, że nie miałem czasu narzekać, choć oczywiście było zimno i ciemno. Wyobraź sobie Polaka, który nie widział Słońca od kilku miesięcy. Ale było tam kilku Norwegów. Nauczyłem się od nich norweskiego. Oczywiście było to ciche i spokojne życie. Jednak przeżyliśmy jedno wydarzenie, które było więcej niż ekscytujące. Po sześciu miesiącach miała

9 Według wzmianki w „Morgenbladet” z 18 IX 1936 r., na pokaz filmu spośród Polaków przybył tylko Konstanty Narkiewicz-Jodko, natomiast według „Norsk Tidend” z tego samego dnia w pokazie wziął udział tylko Siedlecki.

10 Wyprawa miała miejsce w ciągu 8 tygodni lipca, sierpnia i września 1936 r. Powtórnego trawersu Spitsbergenu dokonano dopiero w 1980 r., co może świadczyć o skali tego wyczynu. Zob. P. Köhler, Stanisław Siedlecki (1912-2002), s. 63-64; idem, Druga polska wyprawa na Spitsbergen (w 1936 roku), „Kwartalnik Historii Nauki i Techniki" t. 61, 2016, nr 4, s. 135-143.

11 Po latach Siedlecki nawiązał do wyprawy z 1936 r. w tekście wspomnieniowym Jak Ty kiedyś spotkasz kogoś w potrzebie..., „Biuletyn Polarny” 1995, nr 3, s. 53-64. 
nadejść przesyłka pocztowa z Polski. Norweski statek zatrzymał się na południowym wybrzeżu i holowaliśmy pięć skrzynek z pocztą. Jednak kiedy prawie zostały odholowane na lodowiec, krawędź śniegu pękła i skrzynie, ja i dwaj moi norwescy przyjaciele spadliśmy 50 metrów w dół przez bryły śniegu i lodu prosto w toczące się fale. Na szczęście udało mi się złapać linę i pomóc innym. Ale był luty, ciemno i cały dzień drogi powrotnej do naszej chaty. A co najgorsze, poczta została porwana przez fale.

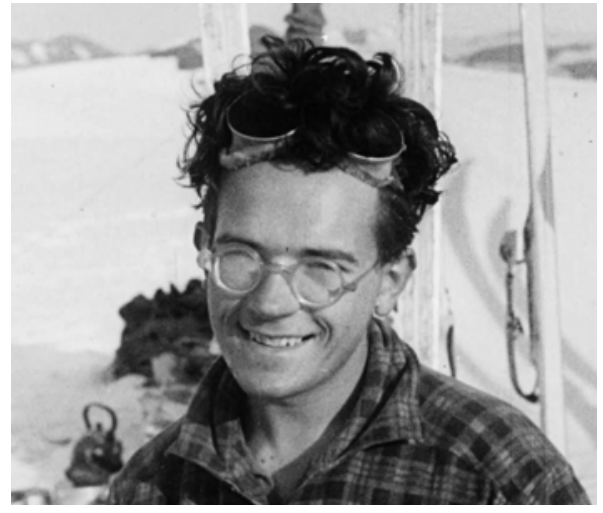

Ryc. 1. Stanisław Siedlecki w 1934 r. (fragment klatki filmu Do Ziemi Torella, reż. W. Biernawski, 1934 r.).

Artykuł kończy się słowami: „Mamy tutaj uroczych przedstawicieli Polski. Entuzjastyczni i oddani badacze i sportowcy"12.

\section{Pierwsze lata powojenne}

Kolejne istotne zetknięcie Siedleckiego z filmem miało miejsce tuż po wojnie. Od wiosny 1945 r. przez pięć lat pracował jako asystent, a potem adiunkt (w 1949 r. obronił doktorat z geologii) w Zakładzie Geologii UJ. W wyzwolonym Krakowie zorganizowano Instytut Filmowy, a w maju 1945 r. jako jego oddział utworzono Filmowy Warsztat Młodych, kierowany przez Antoniego Bohdziewicza i Stanisława Wohla (jego kontynuacją był Kurs Przysposobienia Filmowego) ${ }^{13}$. W 1946 r. powstały w Krakowie dwa filmy, których Siedlecki był współtwórcą: Wieliczka w reżyserii Jarosława Brzozowskiego i Skroplone powietrze (Brzozowski jest wymieniany w bazach jako autor również i tego obrazu). Siedlecki napisał scenariusze obu filmów, pierwszy z nich razem z Brzozowskim. Wieliczka otrzymała Grand Prix na festiwalu w Cannes, stając się pierwszym powojennym polskim filmem oświatowym wyróżnionym za granicą. Rozpoczęta wówczas współpraca przyrodnika (Siedlecki) z filmowcem (Brzozowski) miała z pewnością dziesięć lat później wpływ na obsadę polskiej ekspedycji na Spitsbergen podczas III Międzynarodowego Roku Polarnego (Międzynarodowego Roku Geofizycznego) 1957/1958. Przyrodnikom towarzyszyły dwie ekipy filmowców: jedna kierowana przez Włodzimierza Puchalskiego, druga - przez Brzozowskiego ${ }^{14}$.

V., Polakkar krossar Svalbard på langs, „Norsk Tidend”, 18 IX 1936 r., s. 2. Serdecznie dziękujemy Åsne Ø. Høgetveit za pomoc w tłumaczeniu z tzw. nowonorweskiego (nynorsk).

13 „O obu przedsięwzięciach warto pamiętać z dwóch powodów. Po pierwsze, były one pierwszą skuteczną formą realizacji przedwojennych planów związanych z rozwojem państwowej edukacji filmowej. A po drugie, stworzyły okazję do zespolenia kadr i instytucjonalizacji dydaktyki, dzięki czemu już w 1948 roku udało się uruchomić znacznie bardziej rozbudowaną strukturalnie Szkołę Filmową w Łodzi. Na ciągłość tej tradycji zwraca uwagę Maria Kornatowska”, M. Radkiewicz, Krakowska Prafilmówka 1945-1946, „Pleograf. Kwartalnik Akademii Polskiego Filmu" 2020, nr 1, akademiapolskiegofilmu.pl/pl/historia-polskiego-filmu/pleograf/ edukacja/21/krakowska-prafilmowka-1945-1946/711 [26.09.2020].

14 Marek Hendrykowski wśród wykładowców prowadzących w drugiej połowie lat czterdziestych w Krakowie kurs Przeszkolenia Filmowego, obok m. in. Władysława Tatarkiewicza, Romana Ingardena czy Włodzimierza Puchalskiego, wymienił Stanisława Siedleckiego. Zob. M. Hendrykowski, Jarosław Brzozowski, [w:] (Nie)zapomniani dokumentaliści, red. K. Mąka-Malatyńska, J. Lemann-Zajiček, Łódź 2020, s. 13. 
Wyróżnienie filmu Wieliczka przyćmiło znaczenie filmu Skroplone powietrze i do dziś nie należy on do szczególnie często przywoływanych i analizowanych przez filmoznawców. Jeżeli wspomina się o tym filmie, to zazwyczaj kładzie się nacisk na znaczenie Brzozowskiego w jego powstaniu, nie wymieniając Siedleckiego ${ }^{15}$. Na przykład Małgorzata Radkiewicz w opracowaniu dziejów krakowskiej „prafilmówki” napisała m.in. że aktywność „wileńskiego filmowca” (w rzeczywistości urodził się w Kownie ${ }^{16}$ ) Brzozowskiego:

pozwoliła mu na łączenie zajęć dydaktycznych i produkcyjno-warsztatowych, na czym zawsze zależało Bohdziewiczowi. Na planie filmów Skroplone powietrze i Wieliczka Brzozowskiemu towarzyszyli słuchacze Kursu, których zatrudniał do opracowywania dokumentacji, przygotowywania planu zdjęciowego, pełnienia funkcji asystenckich. Ich zaangażowanie uwiecznili na fotografiach Stefan Brachowski i Eugeniusz Haneman oraz słuchaczka Zofia Lipińska, która w swoich kadrach, zamieszczanych później w „Fotogazetce”, portretowała wykładowców i kolegów"

Na temat obu obrazów można przeczytać w artykule opublikowanym w drugim numerze czasopisma „Film” z 1946 r. Znamienne, że filmowi Skroplone powietrze poświęcono o kilka wersów więcej - tekst powstał tuż po jego realizacji i autor nie mógł sugerować się przyznaniem jakiejkolwiek nagrody (Wieliczce):

"Skroplone powietrze" - to film o odkryciu polskich uczonych: [Zygmunta] Wróblewskiego i [Karola] Olszewskiego, którzy pierwsi w świecie (wbrew fałszującej rzeczywistość propagandzie niemieckiej) dokonali skroplenia powietrza ${ }^{18}$. Film nakręcono w historycznym kolegium uniwersyteckim przy ulicy św. Anny w Krakowie oraz w Zakładach Azotowych w Chorzowie, gdzie wykorzystuje się praktycznie to epokowe odkrycie. Scenariusz i realizację filmu powierzono Stanisławowi Siedleckiemu, zdjęć dokonał Jarosław Brzozowski, współpracował prof. U. J. dr [Tadeusz] Estreicher ${ }^{19}$. Film pt. „Wieliczka” zapoznaje nas z tą starą kopalnią soli, podkreślając jej specyficzne piękno. Film zrealizował Jarosław Brzozowski według scenariusza St. Siedleckiego, kierownikiem zdjęć był Edward Zajiček ${ }^{20}$.

Mimo wątpliwości niektórych filmoznawców na podstawie powyżej przytoczonej publikacji oraz wspomnień ówczesnego kierownika produkcji, Edwarda Zajička, możemy stwierdzić że Skroplone powietrze wyreżyserował Siedlecki, a Brzozowski jedynie współ-

15 Na przykład Hendrykowski autorstwo Skroplonego powietrza przypisał wyłącznie Brzozowskiemu, słowem nie wspominając o wkładzie Siedleckiego. Zob. M. Hendrykowski, Dokument po wojnie. Lata 1945-1949, [w:] Historia polskiego filmu dokumentalnego (1945-2014), red. M. Hendrykowska, Poznań 2018, s. 49. O dysproporcji (lub przypisywaniu przez filmoznawców większego znaczenia filmom uznanym artystycznie za lepsze) świadczy też, że na kolejnej stronie tego opracowania zamieszczono aż siedem kadrów z filmu Wieliczka. Por. Wytwórnia Filmowa Wojska Polskiego Przedsiębiorstwo Państwowe „Film Polski". Katalog produkcji 19431946, Łódź 1947.

16 Por. np. B. Kostrubiec, Ocalić od zapomnienia, jaworzniacy.pl/index.php?option=com_content\&task= view\&id=224 [dostęp 26.09.2020]. Por. M. Hendrykowski, Dokument po wojnie, s. 48-52.

17 M. Radkiewicz, op. cit.

18 Odkrycie miało miejsce 5 IV 1883 r. w Krakowie.

19 Chemik Tadeusz Estreicher (1871-1951) był uczniem Olszewskiego i Wróblewskiego.

20 T., Polski film oświatowy, „Film” 1946, nr 2, s. 7. Informację o autorstwie Siedleckiego potwierdza także M. Łukowski, Polski film przyrodniczy 1945-1986, Łódź 1987, s. 10). Zajiček był kierownikiem produkcji, za zdjęcia odpowiadał Brzozowski. 
pracował (zastąpił Siedleckiego) w ostatnich dniach i mógł film „podpisać" swoim nazwiskiem ${ }^{21}$. Film się zachował i został zdigitalizowany przez Wytwórnię Filmów Oświatowych w Łodzi22. Jego oprawa wizualna i narracja z jednej strony przywodzą na myśl lekcje przedmiotów ścisłych w szkole, przedstawiające spektakularne eksperymenty i wykresy, które swoje istnienie zawdzięczają prawom fizyki i chemii oraz cudom inżynierii, z drugiej stereotypowe obrazy (portrety) ambitnych naukowców (prawdopodobnie napędzanych głodem dominacji nad światem), odważnie obsługujących wyrafinowany sprzęt. Materiał ma niewiele wspólnego z geologią i może świadczyć o wszechstronności zainteresowań i wiedzy Siedleckiego. Elementy filmu fabularnego można również znaleźć w Wieliczce, gdzie zrekonstruowano początki wydobycia soli w Polsce.

Oglądając Wieliczkę, na podstawie czytanego z offu komentarza łatwo można dostrzec wkład Siedleckiego jako geologa. W pierwszych zdaniach pojawia się wyjaśnienie geologiczne, skąd na omawianym terenie pojawiła się sól. Fachowej nomenklaturze towarzyszą bardziej plastyczne metafory, np.

niczym karty papieru lub płaty plasteliny, pomięte zostały i pogięte morskie osady solonośne, zalegające między Karpatami a sztywniejszym blokiem Wyżyny Małopolskiej. Przez ruchy górotwórcze fantastycznie uformowane, złoże solne Wieliczki stanowi wielkie bogactwo naszego $\mathrm{kraju}^{23}$.

Następnie w interesujący sposób zestawiono zainscenizowaną historię techniki pozyskiwania soli w średniowieczu ze współczesnymi możliwościami. Nie pominięto aspektów religijnych, jak sfilmowania kaplicy św. Kingi i wyjaśnienia, że górnicy poszukiwali oparcia w wierze ${ }^{24}$. Swoistym podsumowaniem są ostatnie zwroty, jeśli nie wyłącznie autorstwa Siedleckiego, to przynajmniej stanowiące efekt współpracy scenarzysty z reżyserem:

Z głębin Ziemi, z dawnego dnia morskiego, wydarta rękami górników, jedzie sól do rąk ludzi potrzebujących. Opuszcza Wieliczkę, prastare miasteczko stojące nad plątaniną podziemnych korytarzy największej na świecie kopalni soli, klejnotu naszego górnictwa ${ }^{25}$.

Nawet jeśli w Wieliczce nie było wówczas największej kopalni pod względem ilości rocznego wydobycia soli, wyróżnienie na festiwalu w Cannes świadczy o tym, że była to najlepiej sfilmowana kopalnia soli (a o jej randze turystycznej i znaczeniu kulturowym świadczy późniejszy wpis na pierwszą listę UNESCO, w 1978 r.).

Zachowując chronologię, należy w tym miejscu wspomnieć o wizualnych upamiętnieniach ojca Siedleckiego, Michała ${ }^{26}$. Jego nazwiskiem nazwano dwa polskie statki. Pierw-

21 E. Zajiček, Poza ekranem. Polska kinematografia w latach 1896-2005, Warszawa 2009, s. 77. Według informacji udzielonej nam przez Agnieszkę Polanowską z FINA (której z serdecznie dziękujemy za pomoc w kwerendzie) 2 XI 2020 r. „Zajiček powołuje się na raporty dzienne z produkcji, niestety nie podaje, gdzie się znajdują - to cecha charakterystyczna jego wspomnień. Często oznaczało to, że Zajiček korzystał z materiałów zgromadzonych w swoim archiwum".

22 Za udostępnienie filmu dziękujemy pracownikom archiwum WFO: Jakubowi Krakowiakowi i Markowi Pelskiemu.

23 Wieliczka, reż. J. Brzozowski, 1946 r., 1'25"-1'42".

24 Taki zabieg był możliwy i często stosowany w filmach polskich tuż po wojnie; relacje państwo - Kościół nie były tak napięte, jak w późniejszym okresie, a słaba jeszcze władza komunistów poszukiwała sojusznika; widać to także w historii wizualnej.

25 Wieliczka, reż. J. Brzozowski, 1946 r., 16'0"-16'18".

26 Na temat Michała Siedleckiego (1873-1940) zob. S. Skowron, Michał Siedlecki, [w:] „Wszechświat. Pismo Przy- 
szym był zbudowany w 1947 r. w stoczni James V. Hepburn \& Co. Ltd, Montrose w Wielkiej Brytanii kuter rybacki. Charakterystykę statku przytoczmy według danych opracowanych przez Morski Instytut Rybacki w Gdyni:

Statek ten w 1947 r. otrzymał gdyński „Dalmor" w ramach szeregu dostaw kutrów rybackich dla Polski przez UNRRA (Organizacja Narodów Zjednoczonych ds. Pomocy i Odbudowy). W „Dalmorze” zyskał on nazwę „Aleksy” (GDY 119), obok innych dostarczonych kutrów tego typu (m. in.: „Hilary” (GDY 115), „Walery” (GDY 116), „January” (GDY 117), „Ksawery” (GDY 118). Podniesienie bandery nastąpiło 4.10.1947 r. W lipcu 1948 r. „Aleksy” został przejęty przez Morskie Laboratorium Rybackie w Gdyni (od 01.01.1949 r. już jako MIR). Prace adaptacyjne, przystosowujące kuter rybacki do badań morza, prowadziła Stocznia Remontowa w Gdyni. Po remoncie 6.11.1948 r. statek przyjął nazwę „Michał Siedlecki”. Był statkiem do badań otwartych wód Bałtyku. Kuter ten był jednym z pierwszych (obok „Ewy II”), na którym zapoczątkowano badania mające charakter zwiadu rybackiego na wodach Bałtyku po 1945 roku. Sprzedany przez MIR w 1956 r. ${ }^{27}$

Z końcem 1950 r. operatorzy Polskiej Kroniki Filmowej sfilmowali prace na statku „Sie-

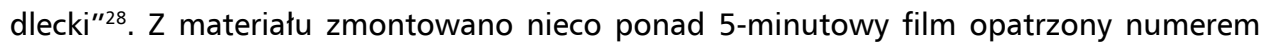
5341 (tytuł Statek badawczy Siedlecki), który nie wszedł do żadnego z wydań Kroniki. Zdjęcia wykonał Janusz Sowiński. Widzimy na nich prace polegające na pobieraniu próbek wody i piasku z dna morskiego. Niektóre ujęcia próbek w szklanych butelkach mają pewne znaczenie artystyczne - interesująco przedstawiają się pokazywane w przyspieszonym tempie rzucane przez fiolki cienie.

Historia polskich ekspedycji arktycznych w aspekcie kontaktów personalnych wiązała się niejednokrotnie z historią filmu. Przykładowo podczas wyprawy na Grenlandię w 1937 r. zetknęli się Stanisław Siedlecki i Alfred Jahnn ${ }^{29}$. Po wojnie Siedlecki współkierował wspomnianym Filmowym Warsztatem Młodych, natomiast Jahn zainicjował w Instytucie Geografii Uniwersytetu Wrocławskiego oddział filmu naukowego. Dziesięć lat po tych powojennych początkach, obaj badacze udali się na Svalbard w ramach Roku Polarnego 1957/1958, mając już konkretne doświadczenia filmowe (a w przypadku Jahna przynajmniej doświadczenie organizacyjne w ramach struktur i funkcji uniwersyteckich). Później razem konsultowali filmy (W Zatoce Białych Niedźwiedzi, 1961 r.; Polarne wyprawy Włodzimierza Puchalskiego, 1986 r.). W filmie o Stanisławie Siedleckim (1988 r.) zamieszczono archiwalne ujęcie najpewniej z 1957/1958 r. - obu badaczy widzimy płynących na jednej łodzi po wodach Arktyki (Siedlecki stoi, Jahn

rodnicze" 1955, z. 8-9, s. 213-217 oraz inne publikacje tego tomu. Por. biogram Siedleckiego autorstwa Stanisława Tadeusza Sroki, w Polskim Słowniku Biograficznym, dostępny on-line: www.ipsb.nina.gov.pl/a/biografia/ michal-marian-siedlecki [dostęp 28.12.2020].

27 mir.gdynia.pl/michal-siedlecki/ [dostęp 24.10.2020].

28 repozytorium.fn.org.pl/?q=pl/node/5184 [dostęp 24.10.2020].

29 Zob. A. Jahn, Złączyła nas Grenlandia, [w:] Pamiątkowa księga przyjaźni, s. 103-108. Jahn był absolwentem Uniwersytetu im. Jana Kazimierza we Lwowie, geomorfologiem, twórcą powojennego ośrodka geograficznego na Uniwersytecie Wrocławskim. Jako badacz polarny rozpoczął karierę od udziału w ekspedycji grenlandzkiej 1937 r.; wziął udział w ekspedycji na Svalbard w ramach wypraw 1957-1958, współtworzył stację Uniwersytetu Wrocławskiego na Spitsbergenie. Jako rektor Uniwersytetu Wrocławskiego poparł studentów w strajku 1968 r., za co został pozbawiony stanowiska. W latach osiemdziesiątych był rzecznikiem przywrócenia Panoramy Racławickiej polskiemu społeczeństwu. 
siedzi i rozmawia). Każdemu z nich poświęcono też przynajmniej po jednym filmowym portrecie (biografii filmowej) ${ }^{30}$.

\section{Międzynarodowy Rok Geofizyczny 1957/1958¹}

Początek polskiej wyprawy na Svalbard zorganizowanej w ramach Międzynarodowego Roku Geofizycznego 1957/1958 pokazano w materiale Polskiej Kroniki Filmowej (temat zatytułowany Na Spitzbergen, PKF nr 28A/57). Film trwa 43 sekundy, pokazuje wnoszenie bagaży, wejście na pokład statku „Bałtyk” i jego odpłynięcie ${ }^{32}$. W krótkim ujęciu sfilmowano Siedleckiego, a lektor Bogdan Niewinowski wymienił go z imienia i nazwiska. Cały, silący się na dowcip, tekst komentarza brzmi następująco:

Na daleką Północ, w krainę wiecznych lodów, ciemności i wichrów, wyruszyła na statku Bałtyk wyprawa polskich uczonych. Wezmą oni udział w badaniach Międzynarodowego Roku Geofizycznego. Docent Stanisław Siedlecki, kierownik wyprawy. Ciekawe, jakie prezenty przywiozą żonom z podbiegunowej pustyni. Kronika życzy szczęśliwej podróży i najwyżej 40 stopni mrozu ${ }^{33}$.

W filmie pokazano także Puchalskiego z żoną oraz parę owczarków podhalańskich, które zabrał ze sobą. W jednym z filmów zrealizowanych już na Svalbardzie sfilmuje potem szczenięta w symbolicznym ujęciu w skrzyni z napisem Made in Poland. Psy Puchalskiego, fakt ich zabrania na wyprawę oraz odpowiednie sfilmowanie mogą być interpretowane jako kolejny dowód na poszukiwanie związku Tatr (Podhala) ze Spitsbergenem, a nieco przekornie nawet jako subtelną formę (wizualnej) kolonizacji arktycznego archipelagu przez Polskę. Na miejscu Puchalski fotografował i filmował głównie naturę; Brzozowski częściowo także sfilmował przy pracy przyrodników.

Siedlecki był bardziej związany z grupą filmowców skupioną wokół Brzozowskiego. W filmie Północna Norwegia niesie wieniec, który ma zostać złożony na pomnik bitwy o Narwik dla upamiętnienia poległych żołnierzy polskich ${ }^{34}$. W filmie Mały reportaż spod bieguna stoi z tyłu małej łódki, będąc przedstawionym przez komentatora jako szef polskiej wyprawy na Spitsbergen, który przetrawersował całą wyspę jeszcze w latach trzydziestych XX w. ${ }^{35}$

Wszystkie materiały filmowe, które powstały podczas tej wyprawy, jak i umiejętne dobranie ludzi filmu do grupy naukowców to zasługa kierownika ekspedycji. Zapoczątkowane polskim udziałem w Międzynarodowym Roku Geofizycznym ekspedycje były kon-

$30 \mathrm{Na}$ temat Jahna zob. film z cyklu Profesor Wrocław, zrealizowany w 2013 r. przez Lenę Kaletową. Za udostępnienie filmu dziękujemy dr. Andrzejowi Traczykowi, któremu film udostępnił dr Jan Klementowski, emerytowany pracownik Instytutu Geografii i Rozwoju Regionalnego Uniwersytetu Wrocławskiego (tego ostatniego możemy zobaczyć w filmie jako konsultanta).

31 Podczas Międzynarodowego Roku Geofizycznego 1957/1958 ekipa Brzozowskiego i Puchalskiego zrealizowały po 5 filmów dokumentalnych. Autorzy analizują je szerzej w przygotowywanej, odrębnej publikacji.

32 Statek „Bałtyk" pojawia się także w filmie Mały reportaż spod bieguna, reż. J. Brzozowski, natomiast fragmenty wszystkich filmów Brzozowskiego zrealizowanych na Svalbardzie wykorzystano w filmie W Zatoce Białych Niedźwiedzi.

33 repozytorium.fn.org.pl/?q=pl/node/6589 [dostęp 20.09.2020].

34 Północna Norwegia, reż. J. Brzozowski, 3'27"-3'29".

35 Mały reportaż spod bieguna, reż. J. Brzozowski, 7'55"-8'4". 


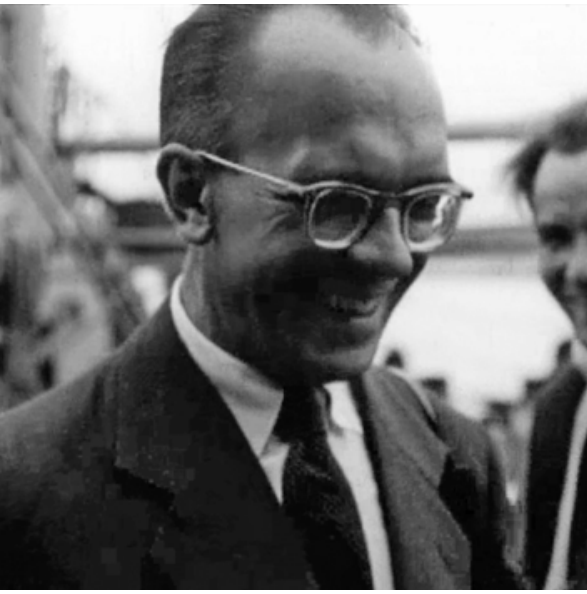

Ryc. 2. Stanisław Siedlecki w 1957 r. (fragment klatki filmu Na Spitzbergen, Polska Kronika Filmowa, 1957, nr 28A). tynuowane. Polska Akademia Nauk założyła bazę (stację polarną) w Hornsundzie, wyprawy odtąd regularnie (pamiętając o newralgicznym okresie połowy lat sześćdziesiątych, gdy budynek stacji podupadł) wracały na Svalbard; całoroczną stację uruchomiono z końcem lat siedemdziesiątych.

Tymczasem w 1960 r. Siedlecki (wraz z m.in. Jahnem) konsultował film $W$ Zatoce Białych Niedźwiedzij6. W tym pełnometrażowym obrazie wykorzystane zostały ujęcia z Polskiej Kroniki Filmowej oraz krótkometrażowych filmów Brzozowskiego. Pokazano okolicę fiordu Hornsund - tytułową zatokę oraz jej naturalnych mieszańców: niedźwiedzie polarne. Komentarz narratora towarzyszący filmowaniu (fotografowaniu) niedźwiedzi („To tylko fotoobiektyw. I tym razem milczą nasze strzelby [...] Fotoamatorzy mogą strzelać do woli, dopóki gościom nie znudzi się kanonada migawek"37) przypomina metaforę Puchalskiego „bezkrwawe łowy”.

W tym filmie Siedlecki pojawia się nie tylko jako konsultant, lecz także jako operator w jednej z pierwszych sekwencji („Zdjęcia doc. Siedlecki”), a także wielokrotnie w kadrze jako w pewnym sensie główny bohater. Jest najczęściej pojawiającą się na ekranie postacią; ze względu na znajomość języka norweskiego i wcześniejsze, przedwojenne doświadczenia, serdecznie wita się z radiowcem Fritzem Øienem (1899-1963) w Tromsø; na Hornsundzie rozmawia z gubernatorem Svalbardu Oddem Birketvedtem (1916-2009); spieszy na pomoc lekarzowi Zbigniewowi Jaworowskiemu (1927-2011). Kontrowersyjnie wówczas mogła być postrzegana scena z ubranym w same majtki Siedleckim, który przechodzi korytarzem budynku stacji polarnej w filmie Brzozowskiego. W pewnym sensie miało to na celu pokazanie swojskiego, prywatnego oblicza uznanego polarnika.

Innymi słowy, W Zatoce Białych Niedźwiedzi zgrabnie podsumowuje to, co postanowiliśmy badać, a mianowicie daje przykłady wszystkich trzech głównych konstelacji Siedlecki - film: „Stanisław Siedlecki w filmie”; „film Stanisława Siedleckiego”; „film o Stanisławie Siedleckim".

Biorąc pod uwagę fakt, że od 1946 r. (a szczególnie w latach 1957-1958) Siedlecki współpracował z Brzozowskim, można przyjąć hipotezę, że konsultował także film fabularny Na białym szlaku (w napisach pojawia się informacja o konsultacji Aliny i Czesława Centkiewiczów). Argumentem jest fakt, że w fabule tej wykorzystano fragmenty z materiałów zrealizowanych przez Brzozowskiego na Spitsbergenie oraz to, że część scen dokręcono w Tatrach, które były tak bliskie i dobrze znane Siedleckiemu. Warto dodać, że Czesław Centkiewicz znał się z Siedleckim (z rocznego pobytu na Wyspie Niedźwiedziej 1932/1933) i mogli się konsultować w czasie realizacji filmu.

37 www.facebook.com/WytworniaFilmowOswiatowych/videos/179202650045822/ [dostęp 14.11.2020]. 
Aby przybliżyć profil naukowy Siedleckiego od lat sześćdziesiątych, przywołajmy fragment opracowania Köhlera:

W 1964 r. uzyskał stypendium Norweskiej Królewskiej Rady Naukowo-Technicznej i w latach 1964-1966 pracował jako geolog w Norweskim Instytucie Polarnym w Oslo. Z ramienia tego instytutu prowadził w okresach letnich prace geologiczne na Wyspie Niedźwiedziej i na Spitsbergenie na Sørkapp Landzie (1964 r.) oraz w rejonie Bellsundu (1965 r.). [...]. W 1965 r. został mianowany profesorem nadzwyczajnym Polskiej Akademii Nauk [...] W 1971 r. przyjął za zgodą ówczesnych władz polskich obywatelstwo norweskie ${ }^{38}$.

31 lipca 1972 r. Stocznia Gdańska przekazała Morskiemu Instytutowi Rybackiemu oceaniczny statek badawczy „Profesor Siedlecki"39. Mimo deklaracji, że tą nazwą "Stocznia Gdańska im. Lenina, miała uhonorować wybitnego polskiego naukowca, zoologa, podróżnika i pisarza - profesora Michała Siedleckiego (1873-1940)"40, możemy jednak założyć, że część ówczesnego społeczeństwa kojarzyła nowy statek ze znanym polarnikiem, a nie przedwojennym profesorem, który nie zajmował się polarnictwem. Na temat „Profesora Siedleckiego" autor współczesnego opracowania we wstępie stwierdził, że był to „największy i najsłynniejszy polski statek naukowo-badawczy dla rybołówstwa, jeden z najnowocześniejszych tego rodzaju na świecie" ${ }^{41}$. Zważywszy na te słowa oraz na fakt, że jednostka kilkakrotnie pływała po wodach Antarktyki, widzimy splot wizualnych skojarzeń: Arktyka - Antarktyka - Michał Siedlecki - Stanisław Siedlecki - Svalbard.

W 1980 r. Stanisław Siedlecki przeszedł na emeryturę. Z lat osiemdziesiątych pochodzą przynajmniej dwa filmy dokumentalne, w których profesor emeritus wypowiadał się jako konsultant. Pierwszy z nich poświecono pamięci zmarłego na Antarktydzie w 1979 r. Puchalskiego (Polarne wyprawy Włodzimierza Puchalskiego, reż. R. Wyrzykowski, 1986 r.). Ze słów Siedleckiego dowiadujemy się nie tylko kim był i jak pracował Puchalski; wypowiedzi te mówią również o nim samym (także o postrzeganiu Arktyki, w tym Svalbardu). W filmie pokazano go jako pierwszego (nawet przed ujęciem tytułowego bohatera). Siedlecki wspominał Puchalskiego:

Zdawałem sobie sprawę z tego, iż jest on świetnym fotografem, że interesuje się przyrodą, ale [...] to była znajomość raczej powierzchowna. Natomiast z chwilą, kiedy podjąłem się organizacji wyprawy na Spitsbergen, zdawałem sobie sprawę że wydarzenie tej miary powinno mieć także dokumentację filmową i dlatego pomyślałem o Puchalskim jako o osobie, która się doskonale nadaje do tych zadań, jakie tam mogłyby filmowca oczekiwać. I rzeczywiście w krótkim czasie nawiązałem osobisty kontakt z Puchalskim i natychmiast nawiązał się między nami już nie tylko kontakt służbowy, ale kontakt czysto przyjacielski: to był człowiek o niesłychanym uroku osobistym, przyrodnik (ja też jestem przyrodnikiem, jakkolwiek ja jestem 
geologiem, on był przyrodnikiem w znaczeniu przyrody żywej), mieliśmy wspólny język i wspólne zainteresowania i w krótkim czasie uzgodniliśmy jego zadanie w wyprawie w2. $^{42}$

Przez większość czasu trwania tej relacji widzimy Siedleckiego, a na końcu wypowiedzi sfilmowano nagłówek z prasy norweskiej pod tytułem To Polakker filmer og skriver bok om Svalbard (Dwóch Polaków filmuje i pisze książkę o Svalbardzie) i podtytule Kort opphold i Troms $\varnothing$ før reisen nordover (Krótki pobyt $w$ Troms $\varnothing$ przed wyjazdem na północ) ${ }^{43}$. Nad nagłówkiem opublikowano fotografię przedstawiającą Włodzimierza Puchalskiego i Janusza Czecza (1928-1998) ${ }^{44}$. Następnie narrator udzielił głosu Krzysztofowi Birkenmajerowi (1929-2019) 45 .

W filmie o Puchalskim Siedlecki - ze względu na to, że zabiera głos najdłużej (i najczęściej, ex aequo z Jahnem po trzy razy) - jawi się jako największy autorytet-konsultant. Po wypowiedzi Birkenmajera opowiadał o realiach pracy operatorskiej Puchalskiego; po tym fragmencie zmontowano wspomnienia kolejnego konsultanta, Jahna, następnie ponownie Birkenmajera, później Norwega Larsa Fastinga (Puchalski zatrudnił go wiosną 1958 r., jako asystenta w pracach polskiej stacji polarnej w Hornsundzie; nauczył się on polskiego i później studiował w Warszawie, uzyskując magisterium z architektury, a następnie został znanym architektem $w$ Trondheim). W połowie filmu ponownie (po raz trzeci od początku) słyszymy Siedleckiego, który tym razem mówi na temat ochrony przyrody na Svalbardzie:

Od niepamiętnych czasów problem ochrony przyrody na Spitsbergenie był zaniedbany. Wyniszczono niektóre gatunki, jednym z ptaków które uznane były na całym świecie za gatunek zagrożony, jest gęś białolica ${ }^{46}$. Te gęsi dawniej gnieździły się tylko na tzw. wyspach puchowych, w odległości ok. 15 km morskiej drogi od naszej zatoki Białego Niedźwiedzia. Obecnie gęsi białolice rozprzestrzeniły się bardzo znacznie, gnieżdżą się w najbliższych okolicach bazy, czego Włodek [Puchalski] nie obserwował ${ }^{47}$.

Koniec filmu odnosi się do ostatniej podróży Puchalskiego - na Antarktydę, gdzie zmarł (według sfilmowanej tablicy na pogrzebie: 12 stycznia 1979 r.; według napisów końcowych filmu: 19 stycznia 1979 r.) i został pochowany.

42 Polarne wyprawy Włodzimierza Puchalskiego, $1986 \mathrm{r}$.

43 To Polakker filmer og skriver bok om Svalbard. Kort opphold i Tromsø før reisen nordover „Nordlys” 6 VI 1958. W tekście jest mowa o pracy nad książką Puchalskiego Przyroda Arktyki (została wydana dopiero w 1968 r.), udziale polskim w Międzynarodowym Roku Geofizycznym, wrażeniach Puchalskiego i Janusza Czecza (zob. niżej) z wyprawy oraz dorobku samego Puchalskiego jako fotografa. Artykuł jest istotny dla popularyzacji polskich „narracji polarnych". Tłumaczenie całego artykułu zamieszczamy w przygotowywanej monografii na temat Svalbardu w filmach polskich (Svalbard in Polish Cinema). Nasze podziękowanie za znalezienie tego artykułu zechce przyjąć p. Ivar Stokkeland z Norwegian Polar Institute.

44 Operator Janusz Czecz był krewnym Puchalskiego. Przez większość życia był związany z WFO; zawsze filmował z ręki, nie używał statywu. Interesujące anegdoty z nim związane opisał w swoich wspomnieniach Leszek Skrzydło, np. „Janusz Czecz, zwany krótko Cyziem, z którego zawsze pokpiwaliśmy, że robiąc zdjęcia rozebranym dziewczynom na plaży, gdy mu nad głową przeleci niepozorna nawet mewa, kamerę skieruje na ptaka" (L. Skrzydło, Z tamtej strony kamery. Czterdzieści lat minęło... w Wytwórni Filmów Oświatowych, Łódź 2008, s. 9, 15-17).

45 Krzysztof Birkenmajer był geologiem, speleologiem, polarnikiem. Badania Spitsbergenu rozpoczął w 1956 r. (ekspedycją kierował Siedlecki). Por. E. Zastawniak, 80. Rocznica urodzin Profesora dr. inż. Krzysztofa Birkenmajera - wybitnego geologa, badacza regionów polarnych, „Przegląd Geologiczny” t. 57, 2009, nr 1, s. 1032-1036.

46 Współcześnie w języku polskim bernikla białolica (Branta leucopsis).

47 Polarne wyprawy Włodzimierza Puchalskiego, $1986 \mathrm{r}$. 
W 1988 r. w Wytwórni Filmów Oświatowych w Łodzi powstał dokument zatytułowany Stanisław Siedleckit8. Pierwsze ujęcie przedstawia tytułowego bohatera spoglądającego w stronę Tatr ze Schroniska pod Morskim Okiem. Jeszcze w trakcie wyświetlenia napisu z tytułem i rokiem produkcji w tle skwierczącego ognia (mającego dodawać klimatu, tworząc aurę gawędy, niczym opowiadanie górala Sabały), Siedlecki rozpoczyna retrospekcję - wizualną autobiografię:

Jeśli miałbym mówić o początkach mojego polarnictwa, musiałbym powiedzieć przede wszystkim o początkach mojego kontaktu z górami, dokładniej biorąc z Tatrami. Musimy się cofnąć do roku 1927. Miałem wtedy 15 lat. Nad domem naszym ciążyło pewne nieszczęście. Moja matka w ciągu wielu lat była ciężko chora i ojciec spełniał dla nas, dla naszej trójki (mego brata, mojej siostry i dla mnie), rolę zarówno ojca, jak i matki. [...] $]^{49}$.

Wspominał, że jego pierwsze doświadczenia z górami datują się od wakacji 1927 r.: brat stryjeczny Marcin Siedlecki, razem ze swoim przyjacielem Frączkiem, duchowni, zabrali go pieszo przez Gubałówkę do Zakopanego. Po drodze Stanisław zamoczył buty i kuzyn kupił mu „prawdziwe” turystyczne buty z bawolej skóry. Taka narracja (opis chorej matki, sentyment do butów z bawolej skóry, trudne dzieciństwo) wpisywała się w „mile widziany" w PRL dyskurs o pochodzeniu: Siedlecki nie zaakcentował, że był synem wpływowego profesora, by dodać kolorytu przeszłości rodziny. O ojcu wspomniał jeszcze w filmie raz, mówiąc o przygotowaniach do udziału w wyprawie na Wyspę Niedźwiedzią w ramach roku polarnego 1932/1933. Uzupełnijmy podstawowe dane o ojcu Siedleckiego, przytaczając ponownie Köhlera:

Michał Siedlecki (1873-1940), zoolog, protozoolog, podróżnik, rzecznik ochrony przyrody i literat, profesor Uniwersytetu Jagiellońskiego, organizator i rektor (1919-1921) Uniwersytetu Stefana Batorego w Wilnie. Aresztowany razem z innymi profesorami Uniwersytetu Jagiellońskiego i Akademii Górniczej w dniu 6 XI w czasie Sonderaktion Krakau, wywieziony został do niemieckiego obozu [koncentracyjnego] w Sachsenhausem, gdzie zmarł w dniu 11 I 194050.

Z dalszych zainscenizowanych wspomnień Siedleckiego wynika, że po sukcesie wyprawy na Wyspę Niedźwiedzią, w pewnej mierze jego zasługą była organizacja samodzielnej (nie w ramach międzynarodowych) polskiej ekspedycji na Spitsbergen w 1934 r. W dokumencie pokazano fragmenty Do Ziemi Torella, w tym przedstawiające poszczególnych

W ramach współpracy Wytwórni Filmów Oświatowych i Telewizji TOYA, powstał cykl programów Filmowe Dziedzictwo Łodzi. W ramach jednego z nich (pierwsza emisja 14 XII 2020 r.) pokazano film Stanisław Siedlecki z prelekcją dr. Jacka Szymali. Program obejrzała dr Anna Siedlecka, wdowa po Stanisławie, która zapoznała się także z maszynopisem niniejszego opracowania. W korespondencji mailowej 2 III 2021 r. Siedlecka na marginesie obejrzanego filmu wspomniała, że „Stanisław Siedlecki zdawał sobie doskonale sprawę z wartości filmu w dziedzinie popularyzowania wiedzy i rejestrowania wydarzeń [...]. W latach budowania polskiej stacji w Isbjørnhamna oraz podczas organizowania wypraw letnich i zimowań, nie miał po prostu czasu na filmowanie, toteż powierzał takie zadania innym uczestnikom, zwłaszcza doświadczonym filmowcom". Siedlecka wspomniała także, że Stanisław pokazywał jej w Trondheim filmy z wyjazdu z drugą żoną (Anną z d. Sorbian) na Jawę. Konkludowała zdaniem: „Stanisław Siedlecki był przede wszystkim POLARNIKIEM, rozmiłowanym w pięknej, surowej, trudnej i niebezpiecznej lub nawet wrogiej przyrodzie podbiegunowej".

49 Stanisław Siedlecki, reż. W. Rollny, 1988 r., 0'21"-0'54".

50 P. Köhler, Stanisław Siedlecki, s. 61. 


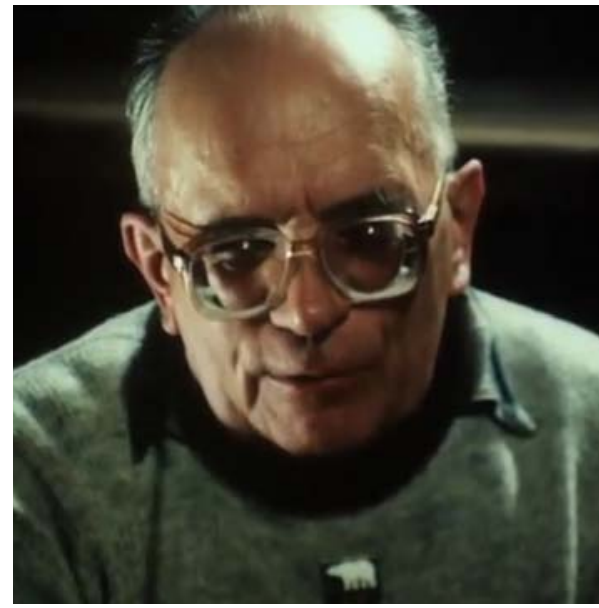

Ryc. 3. Stanisław Siedlecki w 1988 r. (fragment klatki filmu Stanisław Siedlecki, reż. W. Rollny, 1988 r.). członków wyprawy oraz m.in. fragment dokumentujący życie codzienne w obozie. Wynika z tego, ze reżyserka Wanda Rollny miała dostęp do tego materiału, a o fakcie tym i samym filmie (że się zachował) nie wiedział Köhler (i inni przyrodnicy oraz historycy geografii, np. Jan Szupryczyński) przynajmniej do ok. 2015 r. (czas publikacji innych opracowań na temat historii polskiego polarnictwa) $)^{51}$. Filmowa biografia Siedleckiego opowiadana jest chronologicznie. Niejako podsumowaniem części mówiącej o wyprawie z 1934 r. jest fragment tworzący jakoby symboliczny pomost między Polską a Svalbardem (ze względu na geologię, a także historię badań naukowych):

Istotnym celem wyprawy, jak i jej argumentem dla jej przeprowadzenia, był fakt z którego nie wszyscy Polacy sobie zdają sprawę: zaledwie przed kilkunastu-, a tym bardziej kilkudziesięciu tysiącami lat, więcej niż 3/4 terytorium dzisiejszej Polski pokryte było olbrzymim lodowcem. Glacjologia jest nauką, która w Polsce była trochę zaniedbana w okresie przedwojennym, ponieważ po prostu my nie mamy lodowców (jakkolwiek niektóre obszary, jak Tatry, mają charakter morfologii czyli ukształtowania - lodowcowego), jednak lodowce zniknęły. Ażeby prowadzić badania aktualistyczne, to znaczy aby poznać mechanizm tworzenia się osadów lodowcowych, trzeba studiować lodowce żywe. Spitsbergen tych lodowców ma aż w nadmiarze i trzeba powiedzieć, że zarówno pierwsza polska wyprawa na Spitsbergen, jak też cały szereg innych aż do dziś dnia - bardzo często w swoim programie badawczym mają nawracanie do takich czy innych nad przyrodą, nad działaniem, nad mechaniką, nad fizyką lodowców. Można by powiedzieć paradoksalne zdanie, że Spitsbergen jest jak gdyby Polską, ale Polską z epoki lodowej. I tej Polski z epoki lodowej myśmy tam poszukiwali [podkreśl. - J.S., A.R.] ${ }^{52}$.

\section{Lata dziewięćdziesiąte}

Film o Stanisławie Siedleckim zamyka PRL-owski okres w historii polskich filmów z wątkami arktycznymi, zwłaszcza dotyczącymi Svalbardu. W podobnym okresie powstał film

51 Por. np. P. Köhler, Polska wyprawa na Spitsbergen w 1934 roku, „Kwartalnik Historii Nauki i Techniki” t. 60, 2015, nr 2 s. 117-140; J. Szupryczyński, Pierwsza polska wyprawa polarna na Spitsbergen, „Przegląd Geograficzny" t. 87, 2015, nr 1, s. 167-178.

52 Stanisław Siedlecki, reż. W. Rollny, 1988 r., 11'33"-12'49". Podobny powód i argument dla studiowania geomorfologii Svalbardu zawarł w związku z niemiecką ekspedycją z lat 1959-1960 na Barentsøya (Wyspę Barentsa): „W swojej budowie geologicznej Barentsøya ma wiele wspólnego z niektórymi regionami w Niemczech i można sobie wyobrazić, że spore obszary Niemiec podczas ostatniego zlodowacenia wyglądały jak kiedyś jak obecnie Barentsøya" (tłum. własne według Larsa Fastinga, Polakker på Svalbard, [w:] Fastgrodd i landet - livet i nord, b.m. 2017 (Svalbardminner, nr 50), s. 29 (pierwodruk w „Trønder-Avisa” 24 XII 1960 r.). 
Iwony Bartólewskiej Stanisław - syn Michała. Dokument się nie zachował, został zniszczony, być może wraz z innymi materiałami archiwalnymi w okresie tzw. niszczenia teczek zawierających „niewygodne” dane na temat PRL. Na temat filmu wypowiedziała się sama reżyserka podczas rozmowy ze współautorem tego opracowania:

podjęłam pracę równolegle w telewizji i później na uczelni (wykładam nawigację turystyczną); to skoro znalazłam się w miejscu gdzie jest kamera, są specjaliści (bo ja się wtedy w ogóle na tym wszystkim nie znałam) i są operatorzy, są montażyści wspaniali, to uważałam, że [to dobra okazja, aby zrobić film] (bo to było przecież bezpośrednio po 1989 roku, kiedy po raz pierwszy do Polski przyjechał Stanisław Siedlecki). I Stanisław Siedlecki od razu się zgodził, jak mu zaproponowałam żeby po prostu zrobić film z tego, co jest; on udostępnił swoje filmy - realizowane przez siebie (niekoniecznie arktyczne, bo to były również takie filmy, gdzie on zwiedza Amerykę Południową), żeby wykorzystać filmy zrobione na "ósemce" z wyprawy, kiedy [...] Siedlecki razem z Wojtkiem Moskalem ${ }^{53}$ opływa na takich małych łódkach część Spitsbergenu... i St. Siedlecki zgodził się na taką długą gawędę - ta gawęda miała miejsce u mnie w domu, bodajże przez dwa dni pod rząd całe to towarzystwo polarne było... także wszyscy jakby uczestniczyliśmy w tym, żeby zadawać pytania Siedleckiemu, żeby podrzucać pewne pomysły. To było całe towarzystwo związane z wyprawami, które się rozpoczęły w 1977 roku, z środowiska UG (czyli ze środowiska, takiego naturalnego, Marcina Węsławskiego ${ }^{54}$ ), i to byli wszyscy ludzie, którzy wszyscy zgodnie uznawali Siedleckiego za „Papieża Polskiej Arktyki" [podkreśl. - J.S., A.R.] i my wszyscy wyznawaliśmy jego dewizę, mianowicie, że „W życiu należy się czasami bardzo namęczyć, żeby herbata smakowała jak samo życie" - także to było tego typu towarzystwo ${ }^{55}$.

Kolejny dokument Iwony Bartólewskiej z wątkami dotyczącymi Svalbardu, w którym wystąpił Siedlecki, to Polonica arktyczne z 1992 r. ${ }^{56}$ Zarówno w filmie z 1988 r., jak i z 1992 r. Siedlecki wypowiada się jako konsultant, można więc mówić o jego symbolicznej obecności w filmowym obrazie Svalbardu (lub filmowych narracjach o Svalbardzie) przez cały okres PRL aż do czasów transformacji ustrojowej. W filmie Polonica arktyczne Siedlecki wystąpił jako konsultant „tu i teraz”. Po krótkim wprowadzeniu autorstwa Krzysztofa Birkenmajera, cytacie z Antoniego B. Dobrowolskiego, a następnie wypowiedzi Jana Marcina Węsławskiego, Bartólewska zarejestrowała rozmowę trzech emerytowanych profe-

53 Wojciech Moskal, polski podróżnik, polarnik, oceanolog. W 1995 r. towarzyszył Markowi Kamińskiemu w ekspedycji na Biegun Północny; w 2010 r. był konsultantem ds. polarnych w filmie dokumentalnym Koniec Rosji (reż. W. Marczak, 2010 r.).

54 Jan Marcin Węsławski, biolog morski, specjalizuje się m.in. w badaniach flory Arktyki. Spośród publikacji zob. współautorski artykuł wspomnieniowy o Stanisławie Siedleckim: J.M. Węsławski, W. Moskal, M. Zajączkowski, S. Kwaśniewski, J. Jezierski, J. Wiktor, Wspomnienia o Profesorze Stanisławie Siedleckim, „Biuletyn Polarny” 2003, nr 11, s. 16-22. Węsławski publikował na temat Svalbardu w czasopismach „Polar Biology”, „Polar Research" i „Polish Polar Research".

55 I. Bartólewska, zapis rozmowy telefonicznej z J. Szymalą przeprowadzonej 1 grudnia $2020 \mathrm{r}$.

56 Według informacji zawartych na stronie Video Studio Gdańsk (www.videostudio.com.pl/dorobek.html [dostęp 02.03.2021]), film pochodzi z 1993 r., natomiast według internetowej bazy filmpolski.pl kwerenda w Archiwum TVP potwierdziła rok produkcji 1992. Zob. Polonica arktyczne, „Gazeta Telewizyjna” nr 55, 6 III 1993 r., s. 8. Film był emitowany w telewizji przynajmniej dwukrotnie: w 1993 r. oraz w 2011 r. (10 IX 2011 r. na stacji TVP Historia o godz. 21:50), obecnie wersja analogowa dostępna jest w archiwum TVP w Warszawie. 
sorów, prekursorów polskiej polarystyki: obok Siedleckiego siedzą Alfred Jahn i Ryszard Schramm ${ }^{57}$. Konsultanci wypowiadają się o kolejnych polskich wyprawach na Svalbard od lat trzydziestych do osiemdziesiątych. Schramm zwrócił uwagę na polskie nazwy topograficzne na Spitsbergenie, w tym szczyt upamiętniający Mikołaja Kopernika; Jahn porównał przedwojenne polskie wyprawy do pierwszych, dziewiętnastowiecznych prób eksploracji obszarów polarnych, prowadzonych jeszcze w duchu romantyzmu i w ramach wyobrażenia na temat życia traperów. Siedlecki najdłużej i najczęściej pojawia się w filmie; spośród wszystkich ekranowych wypowiedzi jego wspomnienia zajmują tyle czasu ekranowego, co łącznie pozostałych badaczy polarnych.

Wspomnienia Siedleckiego zarejestrowane w Polonicach arktycznych dotyczą kilku aspektów: 1. zimowanie na Wyspie Niedźwiedziej (1932/1933); 2. udział w ekspedycji z 1934 r.; wspomina wówczas o idei nazywania szczytów według polskiej tradycji historycznej; 3. udział w wyprawie 1936 r. - przejście trasy narciarsko-pieszej całego Spitsbergenu z południa na północ i z powrotem; Siedlecki wspomina wówczas opisaną w cytowanym wyżej wywiadzie historię z paliwem do kuchenki ${ }^{58} ; 4$. udział w wyprawie 1957-1958; narrator przed tą sekwencją wypowiedział znamienne zdanie, że „To właśnie polarystyka otworzyła dla Polski żelazną kurtynę w nauce"; sam Siedlecki przywołał okoliczności organizacji tej wyprawy - anegdotę z kolegami, którzy odradzali to przedsięwzięcie, radząc wysłanie „dla reklamy" trzech mężczyzn, aby przezimowali na Svalbardzie i wrócili (historię tę opowiedział także w cytowanym niżej filmie Polska stacja polarna w Hornsundzie); Siedlecki zwrócił też uwagę na opracowane przez niego zasady pracy (oraz obyczaje i normy) w stacji polarnej; 5. reakcja pracowników polskiej stacji polarnej w Hornsundzie wobec wprowadzenia stanu wojennego w Polsce i budowa krzyża na znak solidarności z opozycją i wartościami chrześcijańskimi. Bartólewska zamieściła w filmie także fragment uroczystości jubileuszu 80-lecia Siedleckiego. W imieniu członków Klubu Polarnego Polskiego Towarzystwa Geograficznego gratulacje składa Kazimierz Pękala, Prezes Polskiego Klubu Polarnego). Odpowiedź Siedleckiego zamyka film:

Czuję się głęboko wzruszony. Muszę powiedzieć, że ta ogromna rzesza Kolegów [...], która przeszła przez stację polską na Spitsbergenie [...] to jest cząstka mojego własnego życia. Uważam ich za tych nie tylko następców, ale będących uzasadnieniem pewnego sensu mojego własnego życia. Ja jestem niezmiernie wdzięczny wszystkim Kolegom, którzy brali udział w pracach na tej Dalekiej Północy i wszystkich którzy zrozumieli jedno: że tam myśmy stworzyli Polskę ${ }^{59}$.

Siedleckiego zobaczymy później w filmie Polska stacja polarna w Hornsundzie (1993 r.). Narrator wymienia go już w początkowych zdaniach komentarza:

57 Ryszard Schramm (1920-2007) był biologiem i taternikiem, kilkakrotnie (współ)organizował i kierował wyprawami na Svalbard: w latach 1958, 1965, 1973, 1977, 1980, 1983. Por. z-ne.pl/t,haslo,4285,schramm_ryszard_wiktor.html [dostęp 14.11.2020].

58 Siedlecki przytaczał tę opowieść wiele razy, ustnie i pisemnie. Najbardziej szczegółową wersję (i najbardziej bezpośrednią w znaczeniu źródłowym) mamy w: Tre polakkers ferd over Spitsbergen fra sør til nord (Podróż trzech Polaków przez Spitsbergen z południa na północ), która pierwotnie pojawiła się w czasopiśmie Vi Menn 1977, nr 19-20, a później została przedrukowana w Dramatikk på land og sjø, b.m. 2012, s. 49-50, 54-55 (Svalbardminner, nr 45).

59 Polonica arktyczne, reż. I. Bartólewska, 1992 r., 26'26"-27'10". 
Wyspę odkrył w XVI w. holenderski żeglarz Willem Barents. Dawniej królowali tu traperzy, łowcy foczych i niedźwiedzich futer. Polacy pojawili się wśród fiordów i lodowców Spitsbergenu w latach trzydziestych naszego wieku [równolegle ze zdaniem o Polakach, na ekranie pojawia się fragment mapy z zaznaczonym Lodowcem Siedleckiego pośrodku]. Jednym z pierwszych był prof. Stanisław Siedlecki; dziś: nestor polskich polarników ${ }^{60}$.

Po tym wprowadzeniu widzimy Siedleckiego, który mówi:

Polska jako kraj wolny, która odzyskała wolność po 150 latach rozbiorów, rozpoczęła swoje badania w krajach polarnych, na Spitsbergenie, w 1934 r. (właściwie już w '33 byliśmy na Wyspie Niedźwiedziej, prowadziliśmy w ramach Międzynarodowego Roku Polarnego badania wstępne); a następnie samodzielna polska wyprawa - pierwsza, pojechała na Spitsbergen wykonując tam badania geologiczne, wykonując mapę nieznanego dotychczas terenu. Tym samym Polska weszła na teren nauki światowej i zadokumentowała swoje istnienie. Stacja została wybudowana w związku z Międzynarodowym Rokiem Geofizycznym. Polska otrzymała jako swój punkt badawczy Spitsbergen, naszymi najbliższymi sąsiadami byli Szwedzi, Finowie, Szwajcarzy, Austriacy. Założeniem zatem, moim, przy organizowaniu tej stacji, było, że wybudujemy budynek stacji na miejscu, na Spitsbergenie, że nie będzie to jakieś koczowanie w namiotach i spędzenie tego bądź co bądź trzynasto- czy nawet czternastomiesięcznego czasu w warunkach bardzo prymitywnych, tylko wprost przeciwnie: my stworzymy polską stację badawczą analogiczną do jakichkolwiek stacji badawczych istniejących w Europie. Ten mój pogląd był początkowo bardzo krytykowany przez szereg kolegów, spotkałem się nawet z tego rodzaju zdaniem, że „słuchaj, co ty chcesz, jakąś stację badawczą tam organizować, wystarczy jak poślą dwóch-trzech kolegów, niech tam przezimują w jakimś starym domku traperskim, my już wam zrobimy reklamę" - przyznam się, że tę rozmowę zapamiętałem na całe życie, bo ja ją uważałem za pewnego rodzaju „policzek" w twarz. Nie będę się bawił w reklamę w walącym się gnijącym domku traperskim po to, żeby później twierdzić, że dokonaliśmy jakiegoś wyczynu naukowego. Wprost przeciwnie: jeżeli robimy robotę, to robimy tak dobrą robotę, żeby ona była pewnego rodzaju obliczem Polski na terenie międzynarodowym [podkreśl. - J.S., A.R.] $]^{61}$. w Hornsundzie miała miejsce gorączkowa aktywność. Dwadzieścia cztery godziny podzielono na trzy zmiany, ale w taki sposób, aby każda osoba pracowała szesnaście godzin na dobę, aż stacja była gotowa. Dom o wymiarach 35 x 8 metrów zbudowany został z prefabrykowanych listew. Znajdowało się w nim dziesięć sypialni, kuchnia i jadalnia, pomieszczenie na sprzęt naukowy, akumulatornia, ciemnia, radiostacja i warsztat. Na wschód wzniesiono duży magazyn, który utrzymywał ciepło, gdy jesienią zaczęły wiać zimne wiatry z lodowców. Postawiono sześć 24-metrowych masztów radiowych, dom na generatory elektryczne i garaż. Przechowywano tam również namiot zapasowy, który można wykorzystać na wypadek pożaru. Dwanaście kilometrów od głównej stacji, na lodowcu Werenskiolda, zainstalowano stację obserwacyjną, chatkę, w której dwie osoby mogły przenocować. Mieściła również automatyczny sprzęt rejestrujący" (L. Fasting, Polakker på Svalbard, s. 30). Fasting notował: „W dzisiejszych czasach wyprawy arktyczne mogą być całkiem wygodną sprawą. Na stacji Västisen w Vestfonna w Nordaustlandet [w latach 1957-1959] Szwedzi mieli nawet podłogę z linoleum" (tłum. własne według L. Fasting, En påsketur fra Longyearbyen til Hornsund, [w:] Fastgrodd $i$ landet - livet i nord, s. 23; pierwodruk w „Trønder-Avisa” z 19 IX 1958 r.). 
Po tej wypowiedzi zamieszczono fragment wspomnień innego uczestnika wypraw z 1957/1958 r., Macieja Zalewskiego, po czym ponownie pokazano Siedleckiego. Polarnik wspominał logistykę tego przedsięwzięcia. Wyrażone w początkowej części tej wypowiedzi emocje towarzyszące wypłynięciu ekspedycji uzupełniają przytoczony wyżej fragment Polskiej Kroniki Filmowej, w której widzimy wsiadanie części załogi na statek; natomiast ostatnie sformułowania można interpretować jako lekcję dla młodych polarników, przesłanie na przyszłość:

Oczywiście ostatnie godziny przed opuszczeniem Gdyni i wypłynięciem okrętu hydrograficznego „Bałtyk"62, na którym nasza wyprawa udawała się na Spitsbergen, to były bardzo takie wzniosłe momenty, pożegnanie itd., wzruszenia; dla mnie osobiście uczucie ulgi, że nareszcie wyrusza nasza wyprawa, naprawdę, w drogę na Spitsbergen. W osiem dni po naszym wypłynięciu miał wypłynąć drugi polski statek w ślad za nami. Ten statek to był statek towarowy, polski, „Ustka”, który miał na pokładzie węgiel dla nas (400 t. węgla). „Ustka” zabierała nie tylko węgiel, ale cały ciężki ekwipunek: dom, rozłożony naturalnie na części, żywność na 400 dni dla naszej wyprawy itd. Stacja jest rzeczywiście reprezentantką Polski w dalekim świecie i [tak] jak dotychczas spełniała i będzie niewątpliwie spełniać doskonale rolę takiego naszego konsula kulturalnego, powiedziałbym [podkreśl. - J.S., A.R.]. My mamy co pokazać i chętnie pokazujemy, i uczymy trochę, ten świat, zwłaszcza świat zachodni, o wartościach Polski jako kraju kulturalnego i biorącego udział w badaniach globu ziemskiego. Bo naszą pierwszą ojczyzną jest glob ziemski, a drugą najważniejszą ojczyzną jest własny kraj, Polska [podkreśl. - J.S., A.R.]"63.

\section{Zakończenie}

Jak udało się nam wykazać, biografia Siedleckiego łączyła się z historią polskich filmów, w tym o Svalbardzie, w wielu aspektach na przestrzeni pięćdziesięciu lat. Można stwierdzić, że był to polarnik szczególnie „medialny”: jako „aktor" w filmie Do Ziemi Torella prezentował się bardzo naturalnie, spontanicznie, zawadiacko (szelmowsko) się uśmiechał, energicznym, skocznym krokiem nosił pełne wiadra z wodą; w 1946 r. zrealizował jako scenarzysta dwa filmy (w tym jeden jako współreżyser); następnie swoimi wpływami i organizacją przyczynił się do powstania innych filmów o Svalbardzie, kolejno występował jako konsultant. Siedlecki jako konsultant jawi się jako doskonały gawędziarz, z polotem, bez tremy wypowiadający się na temat polskich badań Arktyki, w tym jego własnych dokonań; często przywołując interesujące niuanse i anegdoty, ważne dla dopełnienia obrazu polskich narracji polarnych.

Z wszystkich opisanych wyżej filmów poznajemy nie tylko samego Siedleckiego, jego stosunek do obszarów polarnych i ich badań, lecz także, czasami mimochodem, czasa-

62 ORP Bałtyk wszedł do służby w polskiej marynarce w 1954 r., został wycofany w 1982 r. i zezłomowany. Miał wyporność 1186 t, długość 69 m, szerokość 9 m, zanurzenie 4,6 m, załoga liczyła 60 osób. Zob. T. Ciesiulewicz, Marynarka Wojenna 1945-1970, Gdańsk 1971.

63 Polska stacja polarna w Hornsundzie, reż. R. Wyrzykowski, 1993 r., 4'36"-6'3". 
mi jako główny temat, przyglądamy się Arktyce jego oczami. Interesujące zdają się być postulaty badań komparatystycznych filmowania (i postrzegania roli filmu) Siedleckiego i Jahna. Tych dwóch przyrodników kilkakrotnie było zresztą zestawianych, nie tylko w bibliografiach prac z zakresu historii polskiego polarnictwa, lecz także w filmach na ten temat, w tym przywołanych wyżej, zwłaszcza Polarne wyprawy Włodzimierza Puchalskiego (1986 r.) i Polonica arktyczne (1992 r.).

\section{Bibliografia}

Ciesiulewicz T., Marynarka Wojenna 1945-1970, Gdańsk 1971.

Dyboski R., Siedlecki M., Przyrodnik a humanista. Dialog, [w:] „Przegląd Współczesny” t. 60,1937 , s. 100-107.

Fastgrodd i landet - livet i nord, b.m. 2017 (Svalbardminner, nr 50).

Hendrykowski M., Dokument po wojnie. Lata 1945-1949, [w:] Historia polskiego filmu dokumentalnego (1945-2014), red. M. Hendrykowska, Poznań 2018, s. 15-85.

Hendrykowski M., Jarosław Brzozowski, [w:] (Nie)zapomniani dokumentaliści, red. K. Mąka-Malatyńska, J. Lemann-Zajiček, tódź 2020, s. 13.

Jahn A., Złączyła nas Grenlandia, [w:] Pamiątkowa księga przyjaźni. Stanisław Siedlecki, red. R.W. Schramm, Poznań 1992, s. 103-108.

Köhler P., Polska wyprawa na Spitsbergen w 1934 roku, „Kwartalnik Historii Nauki i Techniki" t. 60, 2015, nr 2, s. 117-140.

Köhler P., Spuścizna Stanisława Siedleckiego (1912-2002) w zbiorach Zakładu Badań i Dokumentacji Polarnej im. Prof. Zdzisława Czeppego Instytutu Botaniki Uniwersytetu Jagiellońskiego, „Krakowski Rocznik Archiwalny” t. 18, 2012, s. 157-165.

Köhler P., Stanisław Siedlecki (1912-2002) - polarnik, taternik, geolog. Stulecie urodzin, „Kwartalnik Historii Nauki i Techniki” t. 58, 2013, nr 3, s. 61-80.

Kostrubiec B., Ocalić od zapomnienia, jaworzniacy.pl/index.php?option=com_content\&task = view\&id=224 [dostęp 26.9.2020].

Lubowicka A., Jak dołączyć do grona „państw kulturalnych”. Historia wizualna pierwszej polskiej ekspedycji arktycznej w dwudziestoleciu międzywojennym, [w:] Okno na przeszłość. Szkice z historii wizualnej, t. 2, red. D. Skotarczak, J. Szymala, Kraków 2020, s. 35-70, DOI 10.12797/9788381382816.03.

Łukowski M., Polski film przyrodniczy 1945-1986, Łódź 1987.

MacKenzie S., Westerståhl A., The Polarities and Hybridities of Arctic Cinemas, [w:] The Oxford Handbook of Canadian Cinema, red. J. Marchessault, W. Straw, New York 2019, s. 1-2, DOI 10.1093/oxfordhb/9780190229108.013.8.

mir.gdynia.pl/michal-siedlecki/ [dostęp 24.10.2020].

Piltz W., Wieczorek L., Statek badawczy „Profesor Siedlecki”, „Budownictwo Okrętowe” 1973, nr 1, s. 4.

Polonica arktyczne, „Gazeta Telewizyjna” nr 55, 6 III 1993 r.

Radkiewicz M., Krakowska Prafilmówka 1945-1946, „Pleograf. Kwartalnik Akademii Pol-

skiego Filmu" 2020, nr 1, akademiapolskiegofilmu.pl/pl/historia-polskiego-filmu/pleograf/edukacja/21/krakowska-prafilmowka-1945-1946/711 [26.09.2020].

repozytorium.fn.org.pl [dostęp 20.09.2020]. 
Siedlecki S., Jak Ty kiedyś spotkasz kogoś w potrzebie..., „Biuletyn Polarny” 1995, nr 3, s. 53-64.

Siedlecki S. Tre polakkers ferd over Spitsbergen fra sør til nord, [w:] Dramatikk på land og sjø, b.m. 2012, s. 48-60 (Svalbardminner, nr 45)

Skowron S., Michał Siedlecki, [w:] „Wszechświat. Pismo Przyrodnicze” 1955, z. 8-9, s. $213-217$.

Skrzydło L., Z tamtej strony kamery. Czterdzieści lat minęło... w Wytwórni Filmów Oświatowych, Łódź 2008.

Stefański K., Pływające laboratorium. Profesor Siedlecki, „Morze” 2017, sierpień, s. 78.

Szupryczyński J., Pierwsza polska wyprawa polarna na Spitsbergen, „Przegląd Geograficzny" t. 87, 2015, nr 1, s. 167-178.

Szymala J., Rogatchevski A., Svalbard w filmach polskich z lat 30. XX w., „Kwartalnik Filmowy" 2020, nr 112, s. 161-180.

T., Polski film oświatowy, „Film” 1946, nr 2, s. 7.

To Polakker filmer og skriver bok om Svalbard. Kort opphold i Tromsø før reisen nordover „Nordlys" 6 VI 1958 r.

V. Polakkar krossar Svalbard på langs, „Norsk Tidend” 18 IX 1936 r.

Video Studio Gdańsk, www.videostudio.com.pl/dorobek.html [dostęp 02.03.2021].

Wejman M., O rysunkach prof. Michała Siedleckiego, [w:] „Wszechświat. Pismo Przyrodnicze" 1955, z. 8-9, s. 244.

Węsławski J.M., Moskal W., Zajączkowski M., Kwaśniewski S., Jezierski J., Wiktor J., Wspomnienia o Profesorze Stanisławie Siedleckim, „Biuletyn Polarny” 2003, nr 11, s. 16-22.

Wytwórnia Filmowa Wojska Polskiego Przedsiębiorstwo Państwowe „Film Polski". Katalog produkcji 1943-1946, Łódź 1947.

Zajiček E., Poza ekranem. Polska kinematografia w latach 1896-2005, Warszawa 2009.

Zastawniak E., 80. Rocznica urodzin Profesora dr. inż. Krzysztofa Birkenmajera - wybitnego geologa, badacza regionów polarnych, „Przegląd Geologiczny” t. 57, 2009, nr 12 , s. $1032-1036$.

dr Jacek Szymala, badacz historii wizualnej, kulturoznawca, geograf. Redaktor prowadzący serii wydawniczej Historia w Mediach. Aktualne zainteresowania naukowe: historia wizualna, Svalbard, film czarnogórski. Członek Polskiego Towarzystwa Badań nad Filmem i Mediami oraz Polskiego Towarzystwa Badania Gier, wykładowca Akademii Polskiego Filmu.

e-mail: historiawkinie@gmail.com

prof. Andrei Rogatchevski, absolwent Moskiewskiego Uniwersytetu Państwowego im. M.W. Łomonosowa (1988 r., praca magisterska dotycząca języka i literatury rosyjskiej) i Uniwersytetu w Glasgow (1998 r., doktorat w dziedzinie języków i literatur słowiańskich). Obecnie pracuje na stanowisku Profesora Literatury i Kultury Rosyjskiej w UiT The Arctic University of Norway.

e-mail: andrei.rogatchevski@uit.no

Data zgłoszenia artykułu: 28 grudnia 2020

Data przyjęcia do druku: 22 marca 2021 